Piotr Piotrowski*

\title{
Quantitative Estimate of Trees in Urbanized Area Based on Automatic Detection of Afforestation
}

\begin{abstract}
In recent years, inhabitants of Polish towns have been affected by an increasing shortfall in green vegetation. The spatial planning policy in those towns is not currently focused on the formation of new green areas. The crucial information for the proper management of green areas is the number of trees, which reflects the current state of high vegetation in the particular region. The study was conducted in respect to the part of town characteristic of a high rate of intensity in housing development. Hereby, the article presents methodology of the automatic detection of trees based on airborne laser scanning data. The detection of trees was performed based on the canopy modeling of LiDAR data (Light Detection and Ranging). As a result, the information about their situation could be obtained. Thanks to the differences between the DSM (Digital Surface Model) and DTM (Digital Terrain Model), it was possible to create a numerical model of tree crowns, which provided data regarding the heights of respective trees. The essential feature of a tree stand is the number of trees and their spatial density. The parameters change dynamically throughout the entire life span of the tree stand. While carrying out the study using GIS software, the statistics concerning the current state of the tree stand were calculated. The conducted analyses proved that laser data enabled an approximate estimation of the number of trees and provided information about their spatial dimensions.
\end{abstract}

Keywords: number of trees, density of afforestation, CHM, airborne laser scanning

\footnotetext{
* University of Agriculture in Krakow, Faculty of Environmental Engineering and Land Surveying, Department of Agricultural Land Surveying, Cadaster and Photogrammetry, Krakow, Poland
} 


\section{Introduction}

When undertaking the theme of afforestation in towns, it is noteworthy that it makes up an integral part of urbanized areas. Within its borders, each town covers areas where trees grow. These are usually residential or industrial areas, traffic routes, parks, etc. The consequence of progressive urbanization is a drastic reduction in green areas. Parts of these areas could be transformed into municipal parks, but they are often appropriated by developers. The essential aspect is monitoring the current resources of afforestation. It is important for both the expansion and clearance of green areas to be executed in a controlled way. This is very valuable information in the scope of the spatial planning of a given area. In places where these changes take an expansive form, there arises the need to verify the information related to the land use. Thanks to modern technology (ALS - Airborne Laser Scanning), the spatial data is captured, which enables a horizontal and vertical analysis of a tree stand structure. A laser survey delivers information about both the topographic surface and elements of land cover (buildings, vegetation), in the shape of a 3D, irregular "point cloud" [4]. A point cloud typically undergoes the process of classification, where the appropriate points are accorded to the proper types of surfaces. Analyses are performed based on the numerical canopy height model (CHM). $\mathrm{CHM}$ furnishes information about situation of the trees and their relative heights in relation to the land area. CHM is the model created on the basis of the differences between the DSM (Digital Surface Model) and DTM (Digital Terrain Model) models, which shows a spatial distribution of the tree crown. Whereas the DSM represents the elevation characteristics of the surface (including vegetation and man-made structures), the DTM only describes the elevation of the terrain; this operation equals removing the underlying terrain information from all features in the DSM [1]. The principal stage of the detection of afforestation is watershed segmentation, which supplies information about the situations of single trees. This article presents the methodology of detecting tree crowns based on the point cloud acquired by means of the ALS technology. The author presents constraints of this method as well.

\section{Materials and Methodology}

The area of survey was part of a city (Wrocław) with a total area of 160 ha. The city is situated in the southwestern part of Poland in the province of Lower Silesia. It was distinguished in view of the high rate of intensity of housing development and the accessibility of laser data. In order to carry out further accuracy analyses of the detected afforestation, a base map was obtained from the Head Office of Geodesy, Cartography, and City Cadastre in Wrocław (Zarząd Geodezji, Kartografii i Katastru Miejskiego we Wrocławiu). This study was carried out based on a point cloud rendered accessible by the company (MGGP Sp. z o.o.) with its registered office in Tar- 
now. The LiDAR data was obtained by order of the Polish Central Documentation Center of Geodesy and Cartography (Centralny Ośrodek Dokumentacji Geodezyjnej i Kartograficznej). The flight took place in the autumn of 2015. The delivered point cloud was created in Standard II (12 points per square meter) and saved in the LAS format. The height accuracy of such a point cloud is not greater than $0.10 \mathrm{~m}$, whereas the topographic accuracy does not exceed $0.40 \mathrm{~m}$.

The point cloud was divided into the nine following classes in conformity (with the effective standards):

1) Created never, classified (which includes different means of transport, such as cars in the parking areas, overhead transmission lines, concentration of impermanent facilities, and other temporary facilities),

2) Ground,

3) Low vegetation,

4) Medium vegetation,

5) High vegetation,

6) Building,

7) Low Point,

8) Water,

9) Overlap Points [5].

The first stage of the study was the manual verification of the point cloud classification. TerraScan software was used to this end. Points on the surface and those belonging to high vegetation underwent an examination. While analyzing the classification of points rated among the high vegetation, an orthoimage and base map were of use. In most cases, the incorrectly classified points (which ought to be accorded to the ground class) and high vegetation were located on the tops of buildings. Removal of points from the high vegetation class from within the outlines of buildings would be incorrect, since parts of the tree crowns were covered by roof surfaces. Thus, the classification remained unchanged in the point cloud originally obtained.

The next step was to import the point cloud into the SAGA GIS software. Subsequently, the ground class was extracted using the Point Cloud Reclassifier/ Subset Extractor tool. Based on the processed point cloud, the DTM was created with the help of the Point Cloud to Grid tool. Then, a modified DSM model was created solely on the basis of the classes of points, surface, and high vegetation. Both the DTM and DSM models were created based on a 0.5-m cell size. The following stage of the study was the generation of the CHM (by subtracting the DSM from the DTM). To accomplish this task, the Grid Difference function was applied. A necessary step was to remove noise from the model by means of the Gaussian Filter module (Fig. 1). Gaussian filtering can reduce the depth of pits and small peaks; however, the technique remains unable to fully remove commission or omission errors [2]. 


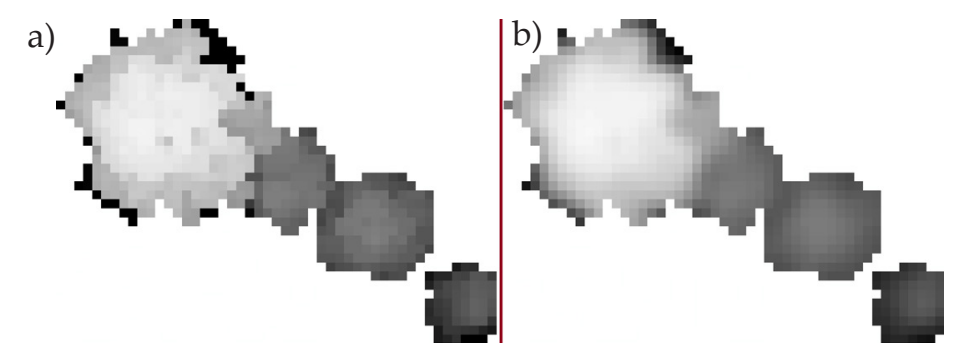

Fig. 1. Gaussian filter effect: a) no filter; b) with its application

The circle search mode, 4-meter search radius, and a standard deviation of 1.35 were applied. The appropriate standard deviation and radius values were selected based on the generation of several models and on their visual assessment. At this moment, a fully valued CHM model was used (Fig. 2). For the purpose of the final detection of particular trees and acquisition of information about their heights, watershed segmentation was used. The tree heights were extracted using the maximum value within the segmented crown boundary [3]. During this process, seed points were also generated (which stand for the treetop). Next, an automatic vectorization of the obtained crown boundaries was performed.

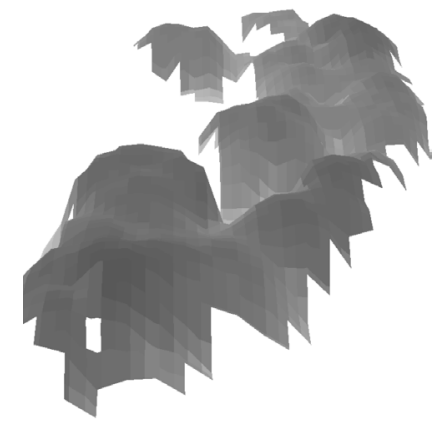

Fig. 2. Piece of canopy height model (3D view)

The generated boundaries and seeds points were saved in the .shp format and further processed in the ArcMap software. The initial stage of filtration was the removal of areas of less than $4 \mathrm{~m}^{2}$. Then, all crowns of the trees with heights of less than $2 \mathrm{~m}$ were excluded. Next, all crowns of trees whose centroids were contained in buildings were removed. Using the orthoimage, vectorized crowns of the trees were subject to inspection, and incorrectly located objects were manually removed if necessary. In order to make a visual presentation of a detected afforestation, centroids inside each crown were generated, and buffers were subsequently created based on them. The generated buffers were of the same surface area as the correspondent irregular crowns. In order to supply spatial information about the tree heights, they were classified in three classes based on the treetop height values obtained from the watershed 
segmentation (Fig. 3). Thanks to this study, it was proven that the vast majority of trees within the examined scope were characterized by heights within a range of 5-15 m.

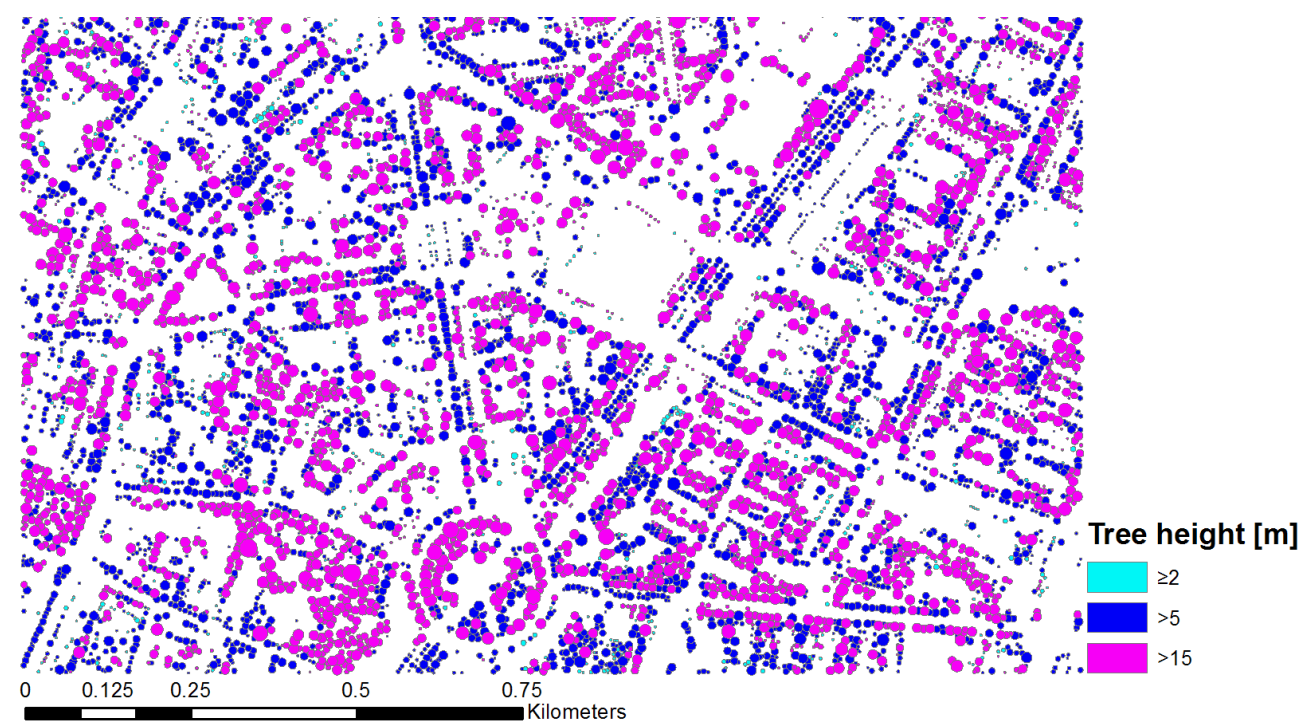

Fig. 3. Tree canopy height map

The following analysis carried out was to generate a density map of the trees. This was calculated using the kernel function based on the number of points (trees) per hectare (Fig. 4). Based on such a study, it is possible to identify the density of the afforestation in a given area.

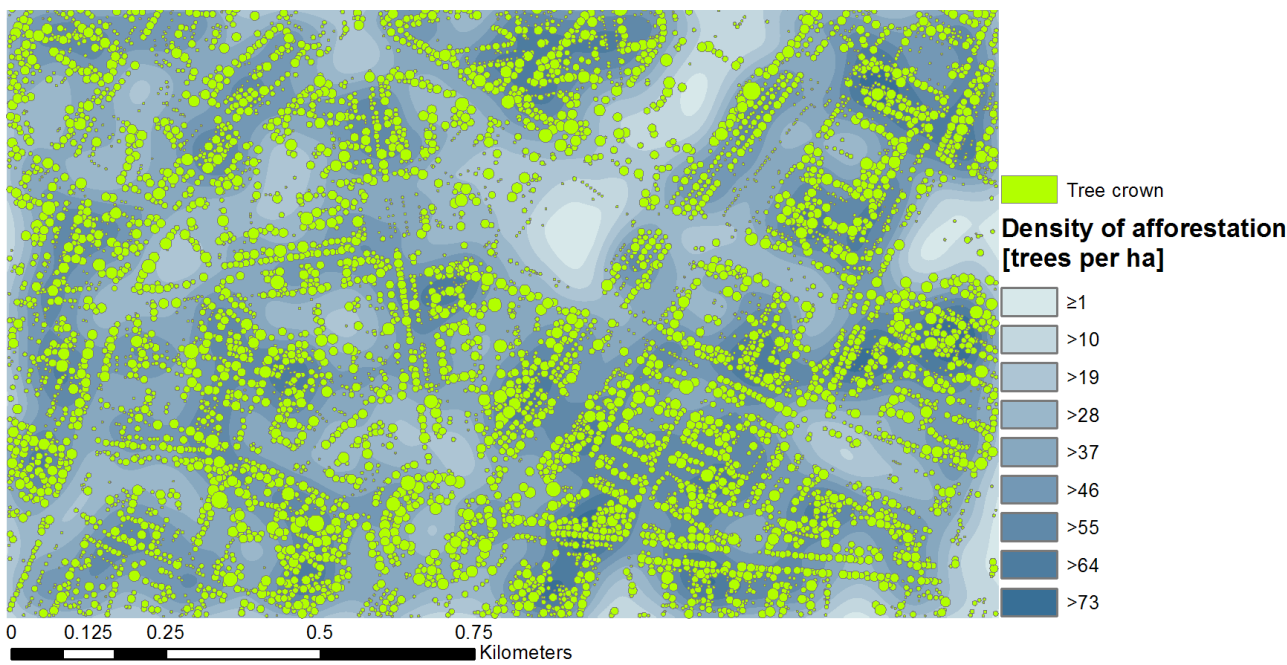

Fig. 4. Tree density map 
In the executed task, the focus was also on a location analysis of the selected trees. In order to verify the correctness of the situation of the detected trees, the base map was applied. Trees shown on the map were defined based on the land survey. Therefore, a comparison of the tree locations of different origins was drawn. The number of 50 correctly detected trees was selected in terms of the analyzed location.

The following statistical values were obtained:

- mean deviation: $1.00 \mathrm{~m}$,

- standard deviation: $0.48 \mathrm{~m}$,

- maximum deviation: $2.19 \mathrm{~m}$,

- minimum deviation: $0.17 \mathrm{~m}$.

\section{Results and Description}

For the inspected area of the city (Wrocław), 6,507 trees were detected in total. Thanks to all stages of data filtration, the incorrectly detected crowns of trees were rejected (which constituted more than twice the number of the final outcome). In addition, the detected trees are correct by the method of manual verification; however, a certain number of trees were not identified. Better results would be achieved by the application of satellite images to carry out the object-oriented classification. Nonetheless, the article presents the method of detecting the trees using the ALS data exclusively. General watershed segmentation methods have problems in that the number of individual trees may be overestimated or underestimated due to the large height variation within their topography or smaller tree tops hidden under the crowns of taller trees [3].

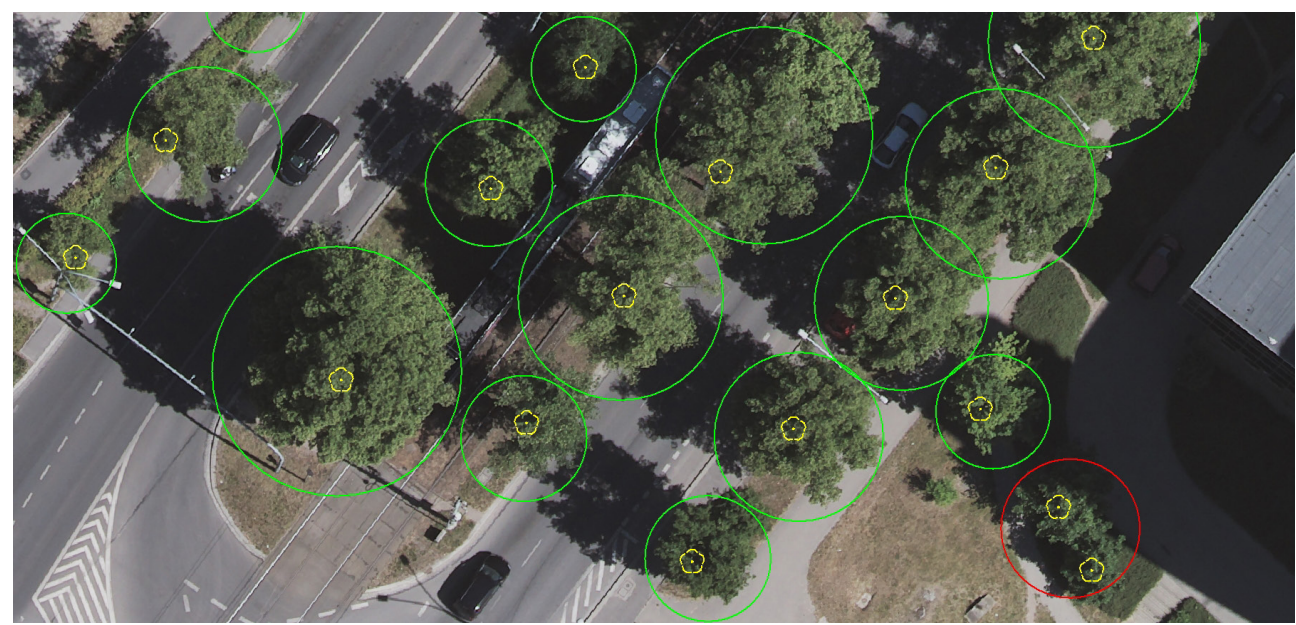

Fig. 5. Automatic tree detection error, in comparison to true situation of trees on base map (yellow) 
In case a manual verification was not carried out, the number of trees might be untrue to a large extent. In the case of performing the aggregation of tree crowns, the pieces of information in terms of the area of afforestation would be correct; however, in respect to the number of trees, they would not be (since two or a group of trees were at times detected as a single tree) (Fig. 5). For the needs of spatial planning in terms of the stand of trees in the particular area, such quantitative data was deemed sufficient.

By analyzing the heights of the appointed trees, a more-beneficial solution would be to extract the point cloud from two different flights. The created DTM model based on the point cloud acquired from a flight in the springtime would best map the area surface. However, the DSM model generated by means of the point cloud acquired in the springtime would in turn best map the luxuriant vegetation. Thus, the heights of the trees would be determined even more accurately.

\section{Summary}

In this study, the capabilities of automatic methods of tree crown detection based on ALS data were analyzed. Thanks to the applied methods of data filtration, the incorrectly detected crowns of trees were excluded. During a visual analysis of a detected afforestation by means of the orthoimage, it was ascertained that an insignificant part of trees was not detected. Also, as Wężyk [6] proved, application of this method ensures the error of underestimation. Low trees that are covered by large tree crowns occur in large numbers in the area of Wrocław, and this makes it impossible to detect them. An example of such an error is presented in Figure 5. An inconsiderable percentage of undetected trees would not affect the general outcome. Hence, it may be assumed that the estimation of the number of trees exclusively on the basis of a point cloud acquired by means of airborne laser scanning leads to a decline in the produced results.

For correctly detected trees selected at random, a mean deviation of $1.00 \mathrm{~m}$ was obtained in relation to the situation of the trees; this was determined based on the land survey and shown on the map.

The usefulness of the CHM model in determining the heights of single trees was proven. The possession of such information makes it possible to carry out further studies; i.e., analyses of shading the object data by individual trees.

\section{References}

[1] Hill A., Breschan J., Mandallaz D.: Accuracy Assessment of Timber Volume Maps Using Forest Inventory Data and LiDAR Canopy Height Models. Forests, vol. 5, no. 9, 2014, pp. 2253-2275. 
[2] Kumar V.: Forest inventory parameters and carbon mapping from airborne lidar. Enschede 2012 [M.Sc. thesis].

[3] Kwak D., Lee W., Lee J., Biging G., Gong P.: Detection of individual trees and estimation of tree height using LiDAR data. Journal of Forest Research, vol. 12, 2007, pp. 425-434.

[4] Mamrol U., Będkowski K.: Dokładność określenia wysokości drzew na podstawie numerycznego modelu koron drzew opracowanego z wykorzystaniem danych lotniczego skanowania laserowego. Archiwum Fotogrametrii, Kartografii i Teledetekcji, vol. 18, 2008, pp. 377-385.

[5] Wężyk P.: Podręcznik dla uczestników szkoleń z wykorzystaniem produktów LiDAR. Główny Urząd Geodezji i Kartografii, Warszawa 2015.

[6] Wężyk P., Tompalski P., De Kok R., Szostak M., Kukawski M.: Metody szacowania liczby drzew w drzewostanie sosnowym z wykorzystaniem danych ALS oraz ortoobrazów. Sylwan, t. 154, z. 11, 2010, pp. 773-782.

\section{Szacunek ilościowy drzew $w$ terenie zurbanizowanym na podstawie automatycznej detekcji zadrzewienia}

Streszczenie: $\mathrm{W}$ ostatnich latach mieszkańcy polskich miast odczuwają skutki rosnącego niedoboru roślinności. Polityka przestrzenna w tych miastach nie skupia się obecnie na formowaniu nowych terenów zielonych. Istotną informacją dla właściwego zarządzania terenami zielonymi jest ilość drzew, która obrazuje stan roślinności wysokiej na danym terenie. Badaniami został objęty fragment miasta charakteryzującego się wysokim wskaźnikiem intensywności zabudowy. Artykuł prezentuje metodykę automatycznej detekcji drzew na podstawie danych pochodzących z lotniczego skaningu laserowego. Zadrzewienie wykrywano z wykorzystaniem modelowania baldachimowego danych LiDAR (Light Detection and Ranging). W rezultacie otrzymano informację o położeniu drzew. Dzięki różnicy modeli DSM (Digital Surface Model) i DTM (Digital Terrain Model) utworzono numeryczny model koron drzew, który dostarczył informacji o wysokości poszczególnych drzew. Ważną cechą drzewostanu jest ilość drzew i ich powierzchniowe zagęszczenie. Parametry te zmieniają się dynamicznie w trakcie całego okresu żywotności drzewostanu. Podczas realizacji badań przy użyciu oprogramowania GIS zostały obliczone statystyki dotyczące stanu istniejącego zadrzewienia. Przeprowadzone analizy wykazały, że dane laserowe umożliwiają przybliżone oszacowanie ilości drzew oraz dostarczają informacji o ich wymiarach.

Słowa

kluczowe: liczba drzew, gęstość zadrzewienia, CHM, lotniczy skaning laserowy, wysokość drzew 